\title{
Monetary Policy Regulation for the Bank of Central African States (BEAC)
}

\author{
Antoine Ngakosso \\ Faculté des Sciences Economiques, Université Marien Ngouabi, Brazzaville, Congo \\ Email:Ngakosso_anrtoine@y ahoo.fr
}

How to cite this paper: Ngakosso, A. (2017) Monetary Policy Regulation for the Bank of Central African States (BEAC). Modern Economy, 8, 1098-1118. https://doi.org/10.4236/me.2017.89076

Received: August 8, 2017

Accepted: September 10, 2017

Published: September 13, 2017

Copyright $\odot 2017$ by author and Scientific Research Publishing Inc. This work is licensed under the Creative Commons Attribution International License (CC BY 4.0).

http://creativecommons.org/licenses/by/4.0/

\begin{abstract}
This paper aims to put forward a reaction function concerning the behaviour of the Bank of the Central African States (BEAC) turned toward the future then increasing the exchange rate to ensure the internal and external balance in the countries of this monetary zone. Based on the CFA currency and US dollar equivalence, it comes out that there is a strong non linearity between the interest rate and the exchange rate gap. The optimal gap level of the exchange rate in long term (short term) beneath which the monetary authorities should try to reduce the nominal interest rate is $277 \mathrm{~F} \mathrm{CFA}(260 \mathrm{~F} \mathrm{CFA})$ and beyond which they will increase to maintain internal and external balance of the economy of the countries in this zone. So, the exchange rate should be taken as a target whose drift should govern the adjustment of the monetary policy instruments notably the interest rate.
\end{abstract}

\section{Keywords}

Exchange Rate, Balance, BEAC Bank, Gap, Reaction Function

\section{Introduction}

Since the 1980s, in most countries, price stability has emerged as a central objective of central banks. The economic stability has been added as a secondary objective to this main objective. Further to the central bankers' consensus in the late 1990s on New Keynesian monetary policy, the Taylor rule [1], elaborated in the context of the US economy with a flexible ${ }^{1}$ exchange rate regime to meet these two objectives which seems to be spreading in almost all central banks. In other words, the Taylor rule [1] has become the rule of thumb for describing the behavior of central banks in monetary policy, while some of them belong to

${ }^{1}$ The exchange rate flexibility is one of the preconditions for the adoption of inflation targeting according to Masson (1997). 
countries in which the fixed exchange rate regime is in effect.

According to the Taylor rule [1], the short-term interest rate must increase when the effective inflation is higher than the central bank's inflation target or when the actual GDP (Gross Domestic Product) is higher than its long-term trend. Conversely, the short-term interest rate should fall when actual inflation is below the central bank's inflation target or when the effective GDP is below potential GDP. The Taylor interest rate calculated in this way is compared with the interest rate observed in the short term to evaluate the adequacy of monetary policy to the fundamental economic data. To this end, an increase in Taylor's interest rate leads the authorities to intervene in the money market by raising their main rate of intervention in the short term.

Taylor's rule leads to a countercyclical monetary policy. As a matter of fact, monetary policy is optimal if it minimizes the inflation gap and the output gap. In addition to ensuring optimal responses to the various economic disruptions, the Taylor rule avoids problems of temporal incoherence and inflationary biases. Moreover, since the LM curve no longer plays a role in economic policy analysis, the Taylor rule is an outcome of the endogenous monetary supply whose economic policy analyzes are focused on the PM curve, i.e., the curve of monetary policy, and hence on the IS-PM model.

Despite the quasi-generalization of the Taylor rule, in the flexible exchange rate regime, it has limits, among which we can mention: the method of constructing unobservable ${ }^{2}$ variables; the target inflation rate is considered a constant ${ }^{3}$; The absence of smoothing of interest rate $^{4}$ fluctuations to reduce the volatility of production, inflation and the equilibrium interest rate [2].

On the basis of these criticisms, the Taylor rule [1] has gradually been revisited.

Firstly, the literature has evolved to the benefit of the "backward looking" rules, that is, the rules whose interest rate reacts to the past variations of the explanatory variables [2] [3] [4] [5].

Secondly, as a result of criticism of past-oriented rules $^{5}$, recent research predicts

${ }^{2}$ Potential output and inflation are the unobservable variables. Concerning the output, it is the method of evaluation that can stand as the limit.

${ }^{3}$ Taylor considers the target inflation rate as a constant whereas it is more efficient when it varies due to time.

${ }^{4}$ This is about the sudden and instantaneous reaction of the interest rate. Indeed, the determination of the interest rate must depend on its values in the past periods. For each period, the interest rate adjusts to the weighted average of the expected interest rate and the realized interest rate during the previous period.

${ }^{5}$ One of the most important criticisms is that of Lucas. It is based on the fact that economic agents do not modify their behavior in accordance with previous policies. As such, he suggests giving up the idea that economists or policy makers rely on past policies and statistics to predict the future behavior of agents. In other words, Lucas suggests that we must rely on expectations to fix the current policy and not to cover past statistics. It is a matter of leaving adaptive expectations to the benefit of rational expectations. In addition to the criticism of Lucas, the economy only reacts to variations of everything or inflation by following the backward-looking version rules. In the case of other types of shock, the central bank following such a rule cannot achieve its objective of price stabilization. This creates distortions in policy-making and negatively affects the credibility and transparency of monetary policy. Finally, a central bank that adopts such a rule can achieve short-term objectives and not long-term objectives. 
to give up such rules and suggests rules directed towards the future "Forward-looking", that is, rules wherein explanatory variables are based on predictions [6]-[15].

Thirdly, in the international context of the 2000s, characterized by the financial and economic crisis, the "integrated approach", i.e. the integrated policy mix, advocates integration of a financial variable into the Taylor rule such as credit [16], money supply [17] or indicators of financial imperfections [18]. However, such a rule seems to be in contradiction with the principle of Tinbergen [19] ${ }^{6}$ that there must be at least as many instruments as there are objectives to be attained.

Then, taking into account the above changes, the literature suggests the introduction of the exchange rate in the initial Taylor rule [20]. Indeed, formalized on the basis of the economic situation of the United States, Taylor's rule [1] describes the monetary policy of an economy with a flexible exchange rate. In such a context, the central bank has the possibility to focus exclusively on internal variables, since exchange rate variations theoretically guarantee external equilibrium. Under these conditions, the introduction of the exchange rate into the Taylor rule to ensure external equilibrium is a duplication.

Finally, under a fixed exchange rate regime, the monetary authorities, in addition to the internal variables, must also preserve the parity of the currency at a more or less fixed level. Under these conditions, the level of the nominal exchange rate becomes an objective in itself, sometimes a priority over any other consideration. Indeed, failure to take the exchange rate into account can lead to exchange rate volatility [21], which affects inflation through the price of imported goods. However, by simultaneously targeting inflation and exchange using the same instrument, which is the interest rate, a central bank may be faced with a conflict of objectives within the meaning of Tinbergen [19]. Indeed, the high volatility of the exchange rate can have consequences on inflation, which undermines the credibility of the central bank.

In the specific context of the countries of the Economic and Monetary Community of Central Africa (CEMAC), since 1970 its central bank, i.e. the Bank of Central African States, aims at monetary stability through Price ratio and an external currency coverage rate by the compulsory foreign exchange reserves to at least $20 \%$.

Of gross external assets. However, since the $\mathrm{FCFA}^{7}$ 's pegging to the euro, with a fixed uncertain parity of $1 €=656$ FCFA, the BEAC now aims at two objectives: Price stability through an inflation target of $3 \%$; The stability of the exchange rate due to the fixed exchange rate regime with the euro. This stability is supposed to promote trade in goods, services and capital with the euro area countries and to stabilize the exchange value of certain variables denominated in foreign currencies (debt External, raw materials) that have a significant impact on the economy.

${ }^{6}$ The interest rate alone cannot achieve three objectives: monetary stability, macro-economic stability and financial stability.

${ }^{7}$ Franc of the financial community in Africa. 
Beyond the two main objectives, Article 21 of the $\mathrm{UMAC}^{8}$ Convention stipulates that the BEAC, without prejudice to the objective of price stability, supports the general economic policies elaborated in the monetary union. This gives the monetary authorities the possibility of taking into account the stabilization of production in BEAC behavior.

The objective of stability of the exchange rate targeted by the BEAC seems to have at least two limits:

- First, the difference in inflation targets between the BEAC and the European Central Bank': Indeed, based on the purchasing power parity theory, the BEAC would target the same inflation target than the one targeted by the European Central Bank, whereas inflation targeted by the BEAC is $3 \%$ and the inflation targeted by the ECB is $2 \%$;

- Second, the difference between the interest rates charged by the European Central Bank and the BEAC ${ }^{10}$ : According to the theory of uncovered parity of interest rates, the BEAC should have the same policy interest rate as The European Central Bank so that the adjustment of the monetary policy (MP) curve is immediate. In other words, the interest rate differential would be equal to the inflation differential.

In light of the summary description of monetary policy and exchange rate regime in the CEMAC countries, the BEAC monetary system is not consistent with the requirements of Mundell's [22] triangle of incompatibility. Since the exchange rate regime is fixed and capital flows freely, the BEAC should not have a monetary policy different from that of the euro area. In other words, since capital flows freely, the objective of independence of monetary policy necessarily requires the floating of the currency of the countries of the BEAC zone. As a result, the differential in the rate of inflation and the interest rate between the euro area and the BEAC zone is likely to have an impact on the exchange rate. This assumes that in a fixed exchange rate regime monetary authorities have an obligation to defend the parity of the currency insofar as the nominal exchange rate does not allow for the absorption of external imbalances. They must ensure that the exchange rate of their currency on the foreign exchange markets is maintained at a level corresponding to the official parity adopted. Under these conditions, Taylor's rule [1] becomes incomplete under fixed exchange rate regimes because it does not allow for external equilibrium. In fact, it is therefore appropriate to adapt a Taylor rule in the context of a fixed exchange rate regime, such as the BEAC member countries. In terms of economic policy, allowing the exchange rate to depreciate can result in a failure in reaching the inflation target, thus threatening the credibility of the Monetary Policy. On the other hand, the defense of money for reasons other than that linked to the transmission of exchange rate fluctuations to domestic prices may require large increases in interest rates, which tend to contract domestic production and degrade the terms of ${ }^{8}$ Monetary Union of Central Africa.

${ }^{9}$ The European bank aims for $2 \%$ rate of inflation of whereas the BEAC targets $3 \%$.

${ }^{10}$ The rates applied by the BEAC are much higher than those charged by the ECB. 
trade. In this effect, since the CEMAC area is small in size, with a fixed exchange rate regime, a very high level of openness and economies that are not very diversified, taking into account the difference between the nominal exchange rate and the Equilibrium real exchange rate in the rule of monetary policy in the countries of this space seems to be justified. On the empirical level, Pavasuthipaisit [23] sought to analyze under what conditions the inclusion of the exchange rate in an interest rate rule is justified. Two types of results emerge from his study. First, it is optimal for a central bank to include the exchange rate variable in the interest rate rule when the degree of transmission of exchange to domestic prices is high and vice versa when this degree of exchange transmission to Domestic prices is low. Second, the degree of integration into international capital markets is also a determining factor in the weight to be given to the objective of stabilizing exchange rates in the conduct of monetary policy. Cross-sectional research on the various emerging economies has shown that the Taylor rule [1] is insufficient because other decision variables should be taken into account [24] [25] [26].

In the Franc zone countries, AVOUYI-DOVI [27] estimated a reaction function for the WAEMU zone by introducing into the Taylor rule [1] the evolution of net external assets which constitute an important variable in the Specific case of a monetary zone characterized by fixed exchange rates. On the aggregate sample for the period 1970 to 2011, the results of the estimate showed that the BCEO essentially responded to changes in net external assets. On the other hand, on a sub-sample for the period 1990 to 2011, the results obtained showed that the BCEO responded to both inflation, the output gap and movements of external assets.

In the case of CEMAC countries, KAMGNA et al. [28] estimated a BEAC response function based on a Taylor rule of the "Forward looking" type, which takes into account the smoothing of the interest rate, the growth of the money supply and the interest rate differentials between the BEAC and France. The results obtained by the authors are relatively in accordance with the theoretical description.

Definitely, the studies carried out on the BCEAO and the BEAC did not take into account the overall macroeconomic balance which presupposes that internal and external equilibrium are simultaneously assured. Accordingly, it looks pertinent to estimate within the framework of the BEAC a reaction function that takes into account both internal equilibrium and external equilibrium. In other words, the aim of this research is to estimate for the BEAC zone a Taylor rule augmented by the difference between the nominal exchange rate and the real equilibrium exchange rate. This rule should make it possible to verify, on the one hand, whether the simultaneous targeting of inflation and exchange using the interest rate would not lead to a conflict of objective between inflation and exchange, and on the other hand, if the inclusion of the exchange rate in the Taylor rule would allow its fluctuations to control the adjustment of the BEAC 
interest rate in order to ensure both internal equilibrium and external equilibrium in The countries of this zone having a single currency at fixed parity with the euro.

The remaining part of this article is structured around two sections: definition and estimation of a reaction function for the BEAC (Section 2); and results and interpretation (Section 3).

\section{Definition and Estimation of a Reaction Function for the BEAC}

The first step is to present the model of the BEAC response function that supports the analysis before indicating its specification for estimation purposes.

\subsection{Presentation of the Model}

In the light of the criticism of Taylor's original rule, several authors have made changes to it, calculating the reference variables differently, or adding other variables such as the exchange rate and the money supply. These variables are specific to the environment in which each Central Bank operates. Thus, in order to take into account the specificities of the economies of the countries of the BEAC zone, it is necessary to make additional modifications to the original Taylor rule. The aim is to integrate additional arguments as explanatory variables, which may have an impact on the decision-making of the monetary authorities when setting policy rates. In this respect, the formulation of the BEAC response function is based on the work of Sachs [6], Orphanides [29], Kozicki [9] and Clarida, Gali and Gerther [11] Rule", by increasing the initial Taylor rule of the gap between the nominal exchange rate and the real equilibrium exchange rate.

In Taylor's initial rule, the interest rate depends on the output gap and the inflation gap observed in the same year. However, the central bank at the time of its decision, does not have these values in progress. At the most, it has delayed preliminary estimates of these aggregates largely subject to corrections [14]. It is therefore important to assume that central bank action can not affect either inflation or short-term income. Thus, in order to have desired effects of monetary policy on output and inflation, it is necessary to replace their current values with their anticipated values. Such a reaction function that takes into account the exchange rate has the advantage of being concerned with both internal equilibrium and external equilibrium. Thus, the equation of the Taylor rule in the forward looking form takes the following form.

$$
\begin{aligned}
i_{t}= & \rho i_{t-1}+(1-\rho)\left[E\left(\pi_{t+n} \backslash W_{t}\right)+r_{t}^{*}\right]+\alpha\left[E\left(\pi_{t+n} \backslash W_{t}\right)-\pi_{t}^{*}\right] \\
& +\beta\left[E\left(y_{t+n} \backslash W_{t}\right)-y_{t}^{*}\right]+\gamma\left[E\left(q_{t} \backslash W_{t}\right)-q_{t}^{*}\right]
\end{aligned}
$$

where of

$i_{t}:$ the short term nominal interest rate

$r_{t}^{*}:$ the real equilibrium interest rate

$E\left(\pi_{t+n} \backslash W_{t}\right)-\pi_{t}^{*}:$ the difference between the expected inflation rate and the target or target inflation rate; 
$E\left(y_{t+n} \backslash W_{t}\right)-y_{t}^{*}:$ the production gap or the gap between the anticipated real GDP and its potential level;

$E\left(q_{t} \backslash W_{t}\right)-q_{t}^{*}:$ the difference between the nominal exchange rate and the real equilibrium exchange rate;

$T$ : means the date on which the BEAC takes the decision;

$\alpha, \beta, \gamma$ are parameters to be estimated, each representing the weight of each deviation.

$\rho$ : is the parameter measuring the degree of smoothing of the interest rate. Its value is between 0 and 1. If $\rho=0$, we are in the presence of the initial Taylor rule.

$n$ : the anticipation horizon (1 year).

$E$ : the operator of mathematical expectation;

$n$ : the period or the anticipation horizon $(1,2,3, \cdots$ years);

$W_{i}$ represents all the information available at date $t$.

The mechanism of partial adjustment of a variable $X$ to its target $X^{*}$ is given by the following equation:

$$
E\left(\pi_{t+n} \backslash W_{t}\right)=\mu_{x} E\left(\pi_{t+n-1} \backslash W_{t}\right)+\left(1-\mu_{x}\right) X^{*}
$$

where $\mu_{x}$ denotes a parameter measuring the credibility of the target. It is between 0 and 1 .

\subsection{The Specification of the Model}

Equation (1) combined with Equation (2) and for $n=1$, gives the specification of the "augmented" Taylor reaction function as follows:

$$
\begin{aligned}
i_{t}= & \rho i_{t-1}+(1-\rho)\left[\mu_{\pi} \pi_{t}+\left(1-\mu_{\pi}\right) \pi^{*}+r_{t}^{*}+\alpha \mu_{\pi}\left(\pi_{t+1}-\pi^{*}\right)\right. \\
& \left.+\beta \mu_{y}\left(y_{t+1}-y^{*}\right)+\gamma \mu_{q}\left(q-q_{t}^{*}\right)\right]
\end{aligned}
$$

$i_{t}$ : the nominal short-term interest rate. It is the endogenous variable which designates the marginal lending rate of the BEAC.

$r_{t}^{*}$ : the real equilibrium interest rate. It is estimated by the neutral ${ }^{11}$ rate. This rate is approached by the growth rate of potential ${ }^{12}$ GDP (Montagivé, 2005);

$\pi_{t+1}-\pi^{*}:$ the difference between the expected inflation rate and the target or target inflation rate;

$y_{t+1}-y^{*}:$ the production gap or the gap between the anticipated real GDP and its potential level. Potential GDP is estimated by the long-run trend of real GDP.

$q-q_{t}^{*}:$ the difference between nominal exchange rate (NRT) and equilibrium real exchange rate (RTB);

$\alpha, \beta, \mathrm{V}$ are the weighting coefficients to be estimated;

$\rho$ : is the parameter measuring the degree of smoothing of the interest rate. Its value is between 0 and 1 ;

Equation (3) can be reformulated as follows:

$$
i_{t}=\rho i_{t-1}+(1-\rho)\left(\pi_{t}+r_{t}^{*}\right)+a\left(\pi_{t+1}-\pi^{*}\right) \pi^{*}+b\left(y_{t+1}-y^{*}\right)+c\left(q-q_{t}^{*}\right)
$$

\footnotetext{
${ }^{11}$ The neutral rate is defined as the interest rate consistent with balanced long-term growth. At equilibrium stage, the interest rate is equal to the growth rate of the economy.

${ }^{12}$ Trends are extracted from the Hodrick Prescott filter with a parameter $\lambda=100$.
} 
With $a=\alpha \mu_{\pi}(1-\rho), b=\beta \mu_{y}(1-\rho)$ and $c=\gamma \mu_{q}(1-\rho)$.

The expected sign of $q, b$ and $c$ is positive when the expected values are higher than the target values, the central bank must raise the interest rate, i.e. carry out a restrictive monetary policy to bring these variables back to their target value. Conversely, the central bank must pursue a monetary policy by lowering the interest rate, i.e. an accommodative monetary policy. Moreover, a high value of the adjustment coefficient of the inflation gap implies a relatively rapid reaction of the interest rate between the expected level of inflation and its target value. Similarly, a high level of b means that the short-term interest rate is very sensitive to the production gap. Finally, a high level of $c$ means that the short-term interest rate is very sensitive to the exchange rate gap. In this regard, the model to be estimated looks as follows:

$$
i_{t}=\rho i_{t-1}+(1-\rho)\left(\pi_{t}+r_{t}^{*}\right)+a\left(\pi_{t+1}-\pi^{*}\right)+b\left[100 * \frac{\left(y_{t+1}-y_{t}^{*}\right)}{y_{t}^{*}}\right]+c\left(q_{t}-q^{*}\right)+\varepsilon_{t}
$$

whereof $i_{t}$ : is the short term nominal interest rate, $\pi_{t}+r_{t}^{*}$ : is the neuter interest rate, $\pi_{t+1}-\pi^{*}:$ is the gap of inflation, $100 * \frac{\left(y_{t+1}-y_{t}^{*}\right)}{y_{t}^{*}}$ : is the gap of production, $q_{t}-q^{*}:$ is the difference of exchange rate, $\varepsilon_{t}:$ is the error term. We assume that $\pi^{*}=3 \%$ and $q^{*}=3002477$.

The calculations of $q^{*}$ are attached in Appendix.

In the light of the aforementioned ideas, our estimation model looks like the following:

$$
i_{t}=\rho i_{t-1}+(1-\rho) i_{\text {neutre }_{t}}+a\left(\text { Ecart }_{\text {inf }_{t+1}}\right)+b\left(\text { Ecart }_{\text {prod }_{t+1}}\right)+c\left(\text { Ecart }_{\text {changet }_{t}}\right)+\varepsilon_{t}
$$

\section{Model Estimation and Interpretation of Results}

The model presented by Equation (4) is estimated before the principal results are interpreted.

\subsection{Estimation of the Model}

Let us first justify the choice of the different variables of the model before its estimation.

\subsubsection{Choice of Variables}

This is mainly the choice of interest rate measure, inflation rate, output gap and exchange rate differential. For this purpose, we use data from the BEAC database and the World Bank indicators CD-ROM, 2015. These data are in annual frequency and cover the period from 1980 to 2015.

As regards the interest rate, the rate used is the refinancing rate of the BEAC in annual variation. Low interest rates imply an accommodative monetary policy, while high interest rates indicate a restrictive monetary policy. In the case of weak currencies, high interest rates generally consist of offsetting the risk of future depreciation according to the unhedged exchange rate parity. 
Since the reaction function is described in terms of a partial adjustment of the interest rate, the interest rate adjusts each period to the weighted average of the interest rate desired and the interest rate realized in the previous period. For the inflation rate, this is the year growth rate of the Consumer Price Index (CPI). The inflation targeted by the BEAC is $3 \%$.

Next, the output gap measure, the expected effective rate $y_{t+1}$ represents the expected growth rate calculated from a real GDP volume index provided by the BEAC statistics. Potential GDP data were constructed after application of the HODRICK-PRESCOTT filter.

Finally, with respect to the difference between the nominal exchange rate and the equilibrium real exchange rate, the cross-exchange rate between the FCFA and the US Dollar was used to obtain the nominal exchange rate ${ }^{13}$. The real equilibrium exchange rate was then calculated.

\subsubsection{The Estimated Model}

The methodologies generally proposed are those of the generalized moments (GMM) or cointegration of Johansen [30]. The method of generalized moments makes it possible, among other things, to control the potential endogeneity of all the explanatory variables. As for the cointegration approach of Johansen, it allows to estimate a robust relation in the presence of non-stationary variables or, in the case of the stationarity of the variables, it can be used if the variables do not have the same order of integration. This latter approach has been favored, in particular because it provides better results. The first step is to evaluate the stationarity of the variables (Table 1).

The results of the unit root tests show that the nominal interest rate and the exchange rate differential are integrated in order of 1 , while the neutral interest rate, the inflation gap and the production gap are integrated in order 0 . All the variables of this equation are thus stationary. Then, the Johansen cointegration test is used insofar as the variables do not have the same order of integration even if they are stationary (Table 2, Table 3 ).

The likelihood ratio test indicates three cointegration equations.

The maximum eigenvalue statistic test indicates three cointegration relationships. The results are given in Tables 4-6.

Table 5 shows that the cointegration rank is 4 . The variables considered are therefore cointegrated.

After the cointegration tests, the estimation of the two-step error correction model can be undertaken.

Step 1: Estimation by the OLS method of the long-term model is done first.

$$
i_{t}=\rho i_{t-1}+(1-\rho) i_{\text {neutre }_{t}}+a\left(\text { Ecart }_{\text {inf }_{t+1}}\right)+b\left(\text { Ecart }_{\text {prod }_{t+1}}\right)+c\left(\text { Ecart }_{\text {changet }_{t}}\right)+\varepsilon_{t}
$$

\footnotetext{
${ }^{13}$ It was through the exchange rate between the euro and the US dollar that we calculated the exchange rate between the FCFA and the US dollar. This implies indirect flexibility between the FCFA and the US dollar. Since the US dollar is the reference currency for international trade, and since the BEAC countries trade with the countries of the European Union and those of the rest of the world, attention should be paid to parity Crossed with the dollar through the euro. Moreover, the economies of the CEMAC countries depend on the prices of natural resources which are highly volatile and moreover denominated in US dollars. Finally the BCE and FED aim to the same rate of inflation that is $2 \%$.
} 
Table 1. Results of the stationarity test of the variables.

\begin{tabular}{lcccc}
\hline & \multicolumn{2}{c}{ Augmented Dickey-Fuller } & \multicolumn{2}{c}{ Phillips-Perron } \\
\hline & $\begin{array}{c}\text { No intercept } \\
\text { No trend }\end{array}$ & $\begin{array}{c}\text { No intercept } \\
\text { No trend }\end{array}$ & $\begin{array}{c}\text { No intercept } \\
\text { No trend }\end{array}$ & $\begin{array}{c}\text { No intercept } \\
\text { No trend }\end{array}$ \\
\hline Nominal interest & $-0.150(1)$ & $-2.069(1)$ & $-0.026(1)$ & $-2.017(1)$ \\
D (Int. nominal) & $-6.194^{* * *}(0)$ & $-6.378^{* * *}(0)$ & $-6.198^{* * *}(0)$ & $-6.382^{* * *}(0)$ \\
Neutre Interest & $-3.377^{* *}(1)$ & $-3.325^{*}(1)$ & $-3.183^{* *}(1)$ & $-3,131(1)$ \\
Inflation gap & $-3.580^{* *}(1)$ & $-3.670^{* *}(1)$ & $-3.228^{* *}(1)$ & $-3.378^{*}(1)$ \\
Production gap & $-2.987^{* *}(1)$ & $-2.931(1)$ & $-2.651^{*}(1)$ & $-2.569(1)$ \\
Exchange gap & $-1.917(1)$ & $-1.960(1)$ & $-1.977(1)$ & $-2.163(1)$ \\
D (Exchange gap) & $-5.077^{* * *}(0)$ & $-4.970^{* * *}(0)$ & $-5.074^{* * *}(0)$ & $-4.968^{* * *}(0)$ \\
\hline
\end{tabular}

Source: Author's estimation.

Table 2. Results cointegration test.

\begin{tabular}{lcccc}
\hline $\begin{array}{l}\text { Number of Eq. } \\
\text { Co. supposed }\end{array}$ & Own value & Likelihood ratio & Critical value at $5 \%$ & Probability $^{* *}$ \\
\hline None $^{*}$ & 0.872496 & $\mathbf{1 3 6 . 0 4 6 9}$ & $\mathbf{6 0 . 0 6 1 4 1}$ & $\mathbf{0 . 0 0 0 0}$ \\
At least one & 0.733676 & $\mathbf{7 0 . 1 3 9 5 3}$ & $\mathbf{4 0 . 1 7 4 9 3}$ & $\mathbf{0 . 0 0 0 0}$ \\
At least two & 0.471157 & $\mathbf{2 7 . 8 0 2 1 5}$ & $\mathbf{2 4 . 2 7 5 9 6}$ & $\mathbf{0 . 0 1 7 2}$ \\
At least three & 0.159552 & 7.416101 & 12.32090 & 0.2856 \\
At least four & 0.056287 & 1.853861 & 4.129906 & 0.2040 \\
\hline
\end{tabular}

Source: Author's estimation.

Table 3. Result of the likelihood ratio test.

\begin{tabular}{lcccc}
\hline $\begin{array}{l}\text { Number of Eq. } \\
\text { de Co. supposed }\end{array}$ & Proper value & $\begin{array}{c}\text { Optimal proper } \\
\text { Statistic value }\end{array}$ & Critical value at 5\% & Probability $^{* *}$ \\
\hline None $^{*}$ & 0.872496 & $\mathbf{6 5 . 9 0 7 3 4}$ & $\mathbf{3 0 . 4 3 9 6 1}$ & $\mathbf{0 . 0 0 0 0}$ \\
At least one & 0.733676 & $\mathbf{4 2 . 3 3 7 3 8}$ & $\mathbf{2 4 . 1 5 9 2 1}$ & $\mathbf{0 . 0 0 0 1}$ \\
At least two & 0.471157 & $\mathbf{2 0 . 3 8 6 0 5}$ & $\mathbf{1 7 . 7 9 7 3 0}$ & $\mathbf{0 . 0 1 9 9}$ \\
At least three & 0.159552 & 5.562240 & 11.22480 & 0.4022 \\
At least four & 0.056287 & 1.853861 & 4.129906 & 0.2040 \\
\hline
\end{tabular}

Source: Author's estimation.

This gives the result in Table 6 and Table 7.

The correlation coefficient is acceptable and indicates that the selected variables account for $92.6 \%$ of the long-term evolution of the nominal interest rate in the BEAC zone. The coefficients of the variables are all significant. The coefficients used for the smoothing of the interest rate and the output gap show the right sign whereas the others do not show the expected sign. 
Table 4. Results of Optimal proper value statistic test.

\begin{tabular}{|c|c|c|c|c|c|}
\hline \multicolumn{6}{|c|}{ Information Criteria by Rank and Model } \\
\hline Data Trend: & None & None & Linear & Linear & Quadratic \\
\hline $\begin{array}{c}\text { Rank or No. } \\
\text { of CEs }\end{array}$ & $\begin{array}{l}\text { No Intercept } \\
\text { No Trend }\end{array}$ & $\begin{array}{c}\text { Intercept No } \\
\text { Trend }\end{array}$ & $\begin{array}{c}\text { Intercept No } \\
\text { Trend }\end{array}$ & $\begin{array}{l}\text { Intercept } \\
\text { Trend }\end{array}$ & $\begin{array}{l}\text { Intercept } \\
\text { Trend }\end{array}$ \\
\hline \multicolumn{6}{|c|}{ Log Likelihood by Rank (rows) and Model (columns) } \\
\hline 0 & -376.1329 & -376.1329 & -374.1703 & -374.1703 & -371.5954 \\
\hline 1 & -343.1792 & -338.9753 & -337.0197 & -330.9493 & -328.6087 \\
\hline 2 & -322.0105 & -316.9847 & -315.8236 & -309.4976 & -307.1573 \\
\hline 3 & -311.8175 & -305.0484 & -303.9696 & -289.2565 & -287.2460 \\
\hline 4 & -309.0364 & -301.8793 & -301.0566 & -285.0365 & -283.5194 \\
\hline 5 & -308.1094 & -300.9215 & -300.9215 & -282.3242 & -282.3242 \\
\hline \multicolumn{6}{|c|}{ Akaike Information Criteria by Rank (rows) and Model (columns) } \\
\hline 0 & 25.07080 & 25.07080 & 25.26064 & 25.26064 & 25.41221 \\
\hline 1 & 23.63620 & 23.43596 & 23.56373 & 23.24683 & 23.35054 \\
\hline 2 & 22.93816 & 22.74905 & 22.86397 & 22.59360 & 22.63483 \\
\hline 3 & 22.92609 & 22.69053 & 22.74810 & 22.01603 & $22.01537^{*}$ \\
\hline 4 & 23.37727 & 23.17995 & 23.19103 & 22.43978 & 22.40746 \\
\hline 5 & 23.94434 & 23.80759 & 23.80759 & 22.95776 & 22.95776 \\
\hline \multicolumn{6}{|c|}{ Schwarz Criteria by Rank (rows) and Model (columns) } \\
\hline 0 & 26.21591 & 26.21591 & 26.63477 & 26.63477 & 27.01536 \\
\hline 1 & 25.23935 & 25.08491 & 25.39590 & 25.12481 & 25.41174 \\
\hline 2 & 24.99935 & 24.90185 & 25.15418 & 24.97542 & 25.15406 \\
\hline 3 & 25.44533 & 25.34717 & 25.49635 & $24.90170^{*}$ & 24.99265 \\
\hline 4 & 26.35455 & 26.34045 & 26.39733 & 25.82930 & 25.84278 \\
\hline 5 & 27.37966 & 27.47193 & 27.47193 & 26.85112 & 26.85112 \\
\hline
\end{tabular}

Source: Author's estimation.

Table 5. Result of the number of cointegration equation by model.

\begin{tabular}{lccccc}
\hline \multicolumn{5}{c}{ Number of Cointegration Equations per Model (significance at 5\%) } \\
\hline Data Trend: & None & None & Linear & Linear & Quadratic \\
Type of Test & $\begin{array}{c}\text { No intercept } \\
\text { No trend }\end{array}$ & $\begin{array}{c}\text { No intercept } \\
\text { No trend }\end{array}$ & No intercept & No intercept & No intercept \\
Ratio of likelihood & 3 & 2 & No trend & No trend \\
Optimal proper value & 3 & 3 & 3 & 3 & 3 \\
\hline
\end{tabular}

Source: Author's estimation.

Step 2: Estimation by the OLS of the relationship of the dynamic model:

$$
\begin{aligned}
D\left(i_{t}\right)= & \delta_{0} D\left(i_{t-1}\right)+\delta_{1} D\left(i_{\text {neutre }_{t}}\right)+\delta_{2} D\left(\text { Ecart }_{\text {int }_{t+1}}\right)+\delta_{3} D\left(\text { Ecart }_{\text {prod }_{t+1}}\right) \\
& +\delta_{4} D\left(\text { Ecart }_{\text {change }_{t}}\right)+\delta_{5} \varepsilon_{t-1}+\mu_{t}
\end{aligned}
$$


Table 6. Result of the step 1.

\begin{tabular}{lcc}
\hline Variables & Coefficients & t-statistic \\
\hline Delayed interest rate & $1.036825^{* * *}$ & 42.33625 \\
Neutre Interest Rate & $-0.051942^{\star}$ & -1.846037 \\
Inflation gap & $-0.049665^{\star}$ & -1.840086 \\
Production gap & $0.070986^{*}$ & 1.954093 \\
Exchange Rate Gap & $-0.001715^{\star}$ & -1.753501 \\
$\mathrm{R}^{2}$ & & 0.925758 \\
Adjusted $\mathrm{R}^{2}$ & & 0.915517 \\
\hline
\end{tabular}

$\left({ }^{* * *}\right)\left(^{* *}\right)\left({ }^{*}\right)(+)$ mean the significance of variables at $99 \%, 95 \%, 90 \%$ and $80 \%$. Source: Author's estimation.

Table 7. Result of the step 2.

\begin{tabular}{lcc}
\hline Variables & Coefficients & t-statistic \\
\hline Delayed Interest Rate & $0.769395^{* * *}$ & 3.071627 \\
Neutre Interest Rate & $-0.076084^{* * *}$ & -3.099374 \\
Inflation Gap & -0.019867 & -0.842835 \\
Production Gap & $0.120137^{* *}$ & 2.514101 \\
Exchange Rate Gap & $-0.002617+$ & -1.205368 \\
Delayed Error retardée & $-1.167263^{* * *}$ & -3.858404 \\
$\mathrm{R}^{2}$ & & 0.601074 \\
Adjusted $\mathrm{R}^{2}$ & & \\
\hline
\end{tabular}

$\left.\left(^{* * *}\right)^{(*}\right)\left(^{*}\right)(+)$ mean the significance of variables at $99 \%, 95 \%, 90 \%$ and $80 \%$. Source: Author's estimation.

With $\delta_{5}$ being the error correction coefficient or the restoring force. The estimation of this equation gives the following results.

The coefficient of determination, equal to $60 \%$, does not appear better than that in the long-term equation. The signs of the coefficients are the same as those of the long-term equation, although their degrees of significance have decreased. The recall force, reflecting the speed of the nominal interest rate adjustment following a shock, is negative and significantly different from zero. It is estimated to be -1.17 and indicates an important error correction mechanism which shows that the imbalances between the variables compensate directly so that the series have a very similar rapid evolution. More specifically, it is possible to adjust more than $100 \%(117 \%)$ of the imbalance between the desired level and the actual level of the nominal interest rate. Thus, a shock observed during one year is entirely reabsorbed after 0.855 years, i.e. 10 months 8 days (10 months 7 days 19 hours and 8 minutes).

In the short term, as well as in the long term, targeting both inflation and exchange creates a conflict of objectives ${ }^{14}$, because the BEAC zone is small, the ${ }^{14}$ The sign of the output gap being contrary to that of the inflation gap and the exchange gap makes it possible to assess the conflict of objective. 
external anchoring is close to the stability objective since imported products represent a very important part of the price index. Under these conditions, there is equivalence between inflation targeting and exchange rate targeting. The significance of the exchange rate gap being higher in the long term, the exchange rate can be targeted in the countries of the BEAC zone because the growth of the countries of this zone is based on exports. As a result, the analysis of the relationship between the nominal interest rate and the exchange rate spread is important.

The validity tests of the model refer to the ARCH, Breush-Godfrey tests and the stability test (Table 8 , Table 9 ).

The probability values are greater than $5 \%$, so the model is homoscedastic. (The deviations are homoscaedastic).

The probability values are greater than $5 \%$, so the errors of the error correction model are uncorrelated. Thus, the estimates obtained seem to be optimal.

Tests of stability: Cusum and square cusum tests
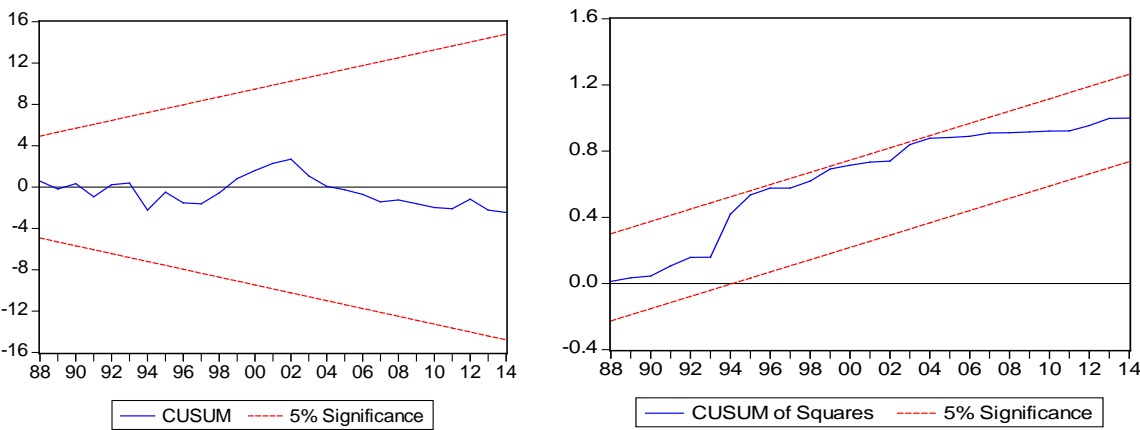

Source: Author's estimation.

Because none of the curves intersects the corridor, the model then appears structurally and punctually stable.

\subsection{Analysis of the Relationship between the Nominal Interest Rate and the Exchange Rate Differential}

The results show a negative and significant relationship of $90 \%$ in the long term and $80 \%$ in the short term. The coefficients estimated at -0.0017 and -0.0026 respectively in the long term and in the short term seem to indicate a decrease in the nominal interest rate of $0.17 \%$ and $0.26 \%$ when the nominal exchange rate increases by 100 points in relation to the real exchange rate. This non-theoretical behavior could be due to a non-linear change in the interest rate and the exchange rate gap ${ }^{15}$. This suggests that there is an optimal level of exchange rate differential below which the BEAC authorities would reduce the interest rate and beyond which the authorities would increase the nominal interest rate. For this purpose, we draw the evolution curves of the three main variables of our model.

Figures 1-3 could suggest a non-linearity between the nominal interest rate and the exchange rate differential.

\footnotetext{
${ }^{15}$ This non linearity could also be worth for nominal interest rate and inflation gap.
} 
Table 8. Result of the ARCH test.

\begin{tabular}{llll}
\hline \multicolumn{3}{c}{ ARCH Test: } \\
\hline F-statistic & 0.641806 & Probability & 0.595035 \\
Obs $^{*} R^{2}$ & 2.068458 & Probability & 0.558320 \\
\hline
\end{tabular}

Source: Author's estimation.

Table 9. Result of the Breush-Godfreytest.

\begin{tabular}{lccc}
\hline \multicolumn{3}{c}{ Breusch-Godfrey Serial Correlation LM Test: } \\
\hline F-statistic & 0.803721 & Probability & 0.458892 \\
$\mathrm{Obs}^{\star} \mathrm{R}^{2}$ & 1.946294 & Probability & 0.377892 \\
\hline
\end{tabular}

Source: Author's estimation.

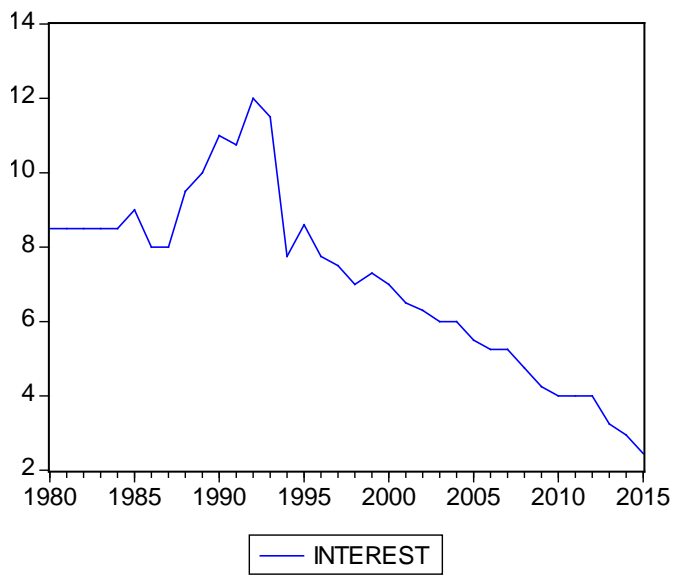

Figure 1. Evolution of Interest rate gap.

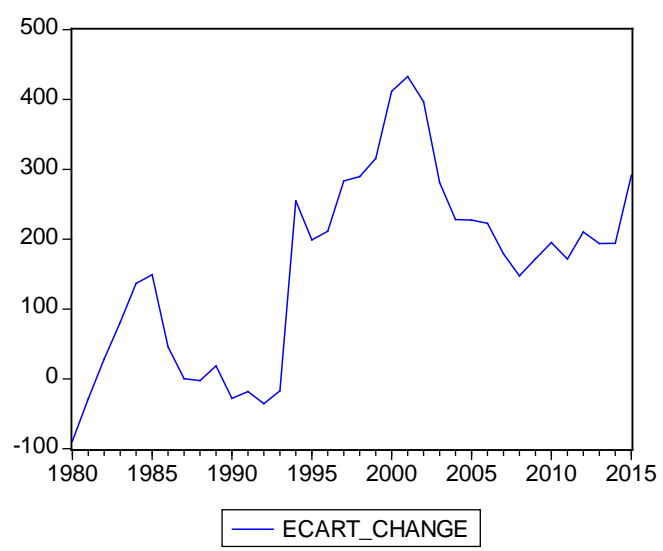

Figure 2. Evolution exchange rate gap.

The simplest way to test this nonlinearity between the nominal interest rate and the exchange rate gap would be to introduce the square of the exchange rate differential as an explanatory variable of the monetary policy instrument. The long-term equation to estimate in this case would be: 


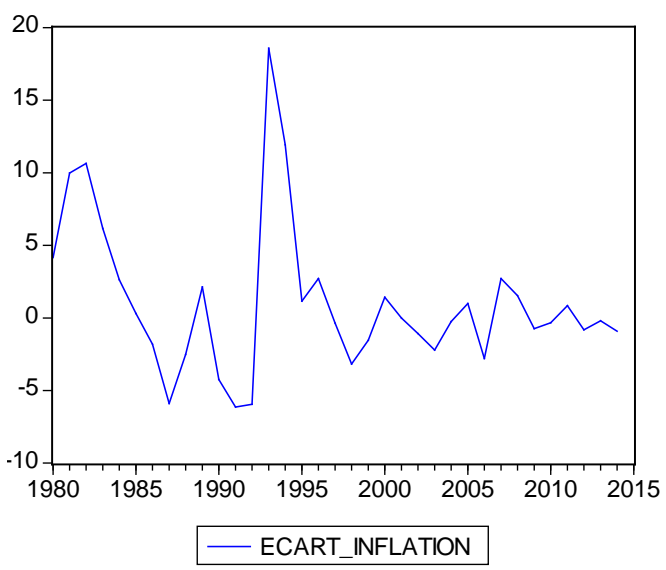

Figure 3. Evolution inflation gap.

$$
\begin{aligned}
i_{t}= & \rho i_{t-1}+(1-\rho) i_{\text {neutre }_{t}}+a\left(\text { Ecart }_{\text {inf }_{t+1}}\right)+b\left(\text { Ecart }_{\text {prod }_{t+1}}\right) \\
& +c\left(\text { Ecart }_{\text {change }_{t}}\right)+d\left(\text { Ecart }_{\text {change }_{t}}\right)^{2}+\varepsilon_{t}
\end{aligned}
$$

Let us therefore test the stationarity of the square of the exchange rate deviation.

Table 10 shows that the square of the exchange rate spread is integrated by order 1, hence stationary. The cointegration test yields the following results:

Table 11 shows that the cointegration rank is 4 . The variables considered are cointegrated. The estimation of the long-term equation gives the results in Table 12.

These results clearly show the possibility of a non-linearity between the nominal interest rate and the exchange rate gap. We should take e as the exchange rate spread

$$
\frac{\delta i_{t}}{\delta e_{t}}=0 \rightarrow-0.0051+0.00001842 e_{t}=0 \rightarrow e_{t}=\frac{0.0051}{0.00001842} \rightarrow e_{t}=276.872964
$$

or $\frac{\delta^{2} i_{t}}{\delta e_{t}^{2}}>0 ; e_{t}^{*}=277$ is a minimum and suggests that the monetary authorities in the BEAC zone would reduce the nominal interest rate when the exchange rate differential is less than 277 . Given that the real equilibrium exchange rate is estimated at $q^{*}=300$, the BEAC would increase the interest rate based on the nominal uncertain exchange rate when the value of the dollar reaches or exceeds the level of 577 CFA francs. Two orientations emerge for this purpose. First, if the nominal exchange rate is less than 577 CFA francs then the foreign exchange differential is less than $277 \mathrm{CFA}$, the BEAC will therefore have to reduce its key interest rate in order to reduce the inflation and non- increase the actual production so that it tends towards the level of potential production. Secondly, if the nominal exchange rate exceeds 577 CFA francs then the exchange rate gap is greater than $277 \mathrm{CFA}$, the BEAC will have to raise its key interest rate to its equilibrium level, Inflation and output. As for the short-term equation, it is specified as follows: 
Table 10. Result of the stationarity test of the square of the exchange rate differential.

\begin{tabular}{lcccc}
\hline & \multicolumn{2}{c}{ Augmented Dickey-Fuller } & \multicolumn{2}{c}{ Phillips-Perron } \\
\hline & $\begin{array}{c}\text { Intercept and } \\
\text { Trend }\end{array}$ & $\begin{array}{c}\text { Intercept and } \\
\text { Trend }\end{array}$ & $\begin{array}{c}\text { Intercept and } \\
\text { Trend }\end{array}$ & $\begin{array}{c}\text { Intercept and } \\
\text { Trend }\end{array}$ \\
\hline (Exchange Gap) $)^{2}$ & $-1560(1)$ & $-2248(1)$ & $-1730(1)$ & $-1902(1)$ \\
$\mathrm{D}(\text { Exchange gap })^{2}$ & $-4285^{* * *}(0)$ & $-4198^{* *}(0)$ & $-4196^{* * *}(0)$ & $-4144^{* *}(0)$ \\
\hline
\end{tabular}

Source: Author's estimation.

Table 11. Cointegration Test.

\begin{tabular}{lccccc}
\hline \multicolumn{5}{c}{ Number of Conintegration Equations by Model (significance at 5\%) } \\
\hline Data Trend: & None & None & Linear & Linear & Quadratic \\
Type de Test & $\begin{array}{c}\text { No Intercept } \\
\text { No Trend }\end{array}$ & $\begin{array}{c}\text { Intercept No } \\
\text { Trend }\end{array}$ & $\begin{array}{c}\text { No Intercept } \\
\text { No Trend }\end{array}$ & $\begin{array}{c}\text { Intercept } \\
\text { With Trend }\end{array}$ & $\begin{array}{c}\text { Intercept With Trend } \\
\text { Likelihood Ratio }\end{array}$ \\
Maximum Proper Value & 3 & 4 & 4 & 4 & 4 \\
\hline
\end{tabular}

Source: Author's estimation.

Table 12. Result of long term estimation.

\begin{tabular}{lcc}
\hline Variables & Coefficients & t-statistic \\
\hline Dealayed Interest Rate & $1.033059^{* * *}$ & 42.27189 \\
Neutre Interest Rate & $-0.040719+$ & -1.391224 \\
Inflation Gap & $-0.052373^{*}$ & -1.953018 \\
Production Gap & $0.093006^{* *}$ & 2.322984 \\
Exchange Rate Gap & $-0.005085^{*}$ & -1.778707 \\
(Exchange Rate Gap)2 & $9.21 \mathrm{E}-06+$ & 1.253085 \\
R2 & & \\
Adjusted R2 & & 0.9297 \\
\hline
\end{tabular}

$\left(^{* * *}\left({ }^{* *}\right)\left(^{*}\right)(+)\right.$ mean the significance of variables at $99 \%, 95 \%, 90 \%$ and $80 \%$. Source: Author's estimation.

$$
\begin{aligned}
i_{t}= & \delta_{0} D\left(i_{t-1}\right)+\delta_{1} D\left(i_{\text {neutre }_{t}}\right)+\delta_{2} D\left(\text { Ecart }_{\text {inf }_{t+1}}\right)+\delta_{3} D\left(\text { Ecart }_{\text {prod }_{t+1}}\right) \\
& +\delta_{4} D\left(\text { Ecart }_{\text {change }_{t}}\right)+\delta_{5} D\left(\text { Ecart }_{\text {change }_{t}}\right)^{2}+\delta_{6} \varepsilon_{t-1}
\end{aligned}
$$

$\delta_{6}$ is the error correction coefficient or the restoring force. The estimation of this equation gives the following results (Table 13).

The restoring force is identical to that of -1.17 found previously. As with the long-run, the non-linear nature of the relationship between the nominal interest rate and the exchange rate gap seems to be confirmed by the short-run equation.

$$
\frac{\delta i_{t}}{\delta e_{t}}=0 \rightarrow-0.0075+0.000029 e_{t}=0 \rightarrow e_{t}=\frac{0.0075}{0.0000290} \rightarrow e_{t}=260.37931
$$


Table 13. Results of the short-term estimate.

\begin{tabular}{lcc}
\hline Variables & Coefficients & t-statistic \\
\hline Delayed Interest Rate & $0.696916^{* * *}$ & 3.141947 \\
Neutre Interest Rate & $-0.064918+$ & -2.692904 \\
Inflation Gap & -0.013014 & -0.594898 \\
Production Gap & $0.133181^{* * *}$ & 2.951653 \\
Exchange Rate Gap & $-0.007551^{*}$ & -1.998637 \\
(Exchange Rate Gap) & & 1.803370 \\
Delayed Error & $1.45 \mathrm{E}-05^{*}$ & -4.187106 \\
$\mathrm{R}^{2}$ & $-1.169756^{* * *}$ & \\
Adjusted $\mathrm{R}^{2}$ & & 0.6613 \\
\hline
\end{tabular}

$\left({ }^{* * *}\right)\left({ }^{* *}\right)\left(^{*}\right)(+)$ mean the significance of variables at $99 \%, 95 \%, 90 \%$ and $80 \%$. Source: Author's estimation.

or $\frac{\delta^{2} i_{t}}{\delta e_{t}^{2}}>0, e_{t}^{*}=260$ is a minimum and suggests that monetary authorities in

the BEAC zone reduce the nominal short-term interest rate when the exchange rate gap is less than 260. Since the real equilibrium exchange rate is $q^{*}=300$, the BEAC would increase the interest rate according to the nominal exchange rate at uncertainty when the value of the dollar reaches or exceeds the level of 560 CFA francs. Two orientations also emerge:

- if the nominal exchange rate is less than $560 \mathrm{CFA}$ then the exchange difference is less than $260 \mathrm{CFA}$, the BEAC will have to reduce its key interest rate in order to reduce the inflation gap and to increase Actual production so that it tends towards the level of potential output;

- if the nominal exchange rate exceeds 560 CFA then the exchange rate difference is greater than $260 \mathrm{CFA}$, the BEAC will have to increase its key interest rate to bring it back to its equilibrium level in order to reduce the gap Inflation and production.

\section{Conclusions}

In order to ensure internal balance and external equilibrium in the BEAC countries, a Taylor rule based on the future, plus the exchange rate, has been designed and estimated. Due to the particularity of the Bank of Central African States (BEAC) monetary zone, the use of cross-parity between the FCFA and the US dollar enabled the real equilibrium exchange rate to the uncertainty of 300 FCFA. Since the BEAC is small and very open, there is an equivalence between inflation targeting and exchange rate targeting. The significance of the exchange difference is higher than that of inflation, so the exchange rate gap is chosen as a target in the countries of the BEAC zone.

Due to the non-linearity between the nominal interest rate and the exchange rate differential, the square of the exchange rate differential was introduced as an 
explanatory variable of the BEAC monetary policy instrument. Thus, with a real equilibrium exchange rate at uncertainty estimated at $300 \mathrm{CFA}$, in the long term when the exchange rate differential is less than $277 \mathrm{CFA}$, the monetary authorities of the BEAC are supposed to reduce the exchange rate, Nominal interest. On the other hand, they would increase it when the exchange rate differential is greater than 277 CFA, i.e. when the uncertain exchange rate between the CFA franc and the US dollar reaches or exceeds the level of 577 CFA. In the short term, the $\mathrm{BEAC}$ authorities must reduce the nominal interest rate when the exchange rate differential is less than 260 CFA. However, when the difference is greater than $260 \mathrm{CFA}$, i.e. when the uncertain nominal exchange rate between the CFA franc and the dollar reaches or exceeds the level of 560 CFA, the BEAC authorities must increase the nominal interest rate.

Finally, taking into account, on the one hand, the cross-parity between the FCFA and the US dollar, and on the other hand, the real equilibrium exchange rate between the FCFA and the US dollar, the interest rate Nominal is a good instrument for achieving both internal balance and external equilibrium in the countries of the BEAC zone. BEAC authorities should therefore conduct their monetary policy based on the exchange rate between the FCFA and the US dollar. The exchange rate should thus be considered as a priority objective of monetary policy in the BEAC zone. To this end, the exchange rate should be targeted, the fluctuations of which should command the adjustment of monetary policy instruments.

\section{Acknowledgements}

I sincerely thank Professor ADAMA Diaw for his insightful remarks which helped me improve the quality of this article.

\section{References}

[1] Taylor, J.B. (1993) Discretion versus Policy Rules in Practice. Carnegie-Rochester Conference Series on Public Policy, 39, 195-294.

[2] Levin, A., Wicland, V. and Williams, J.C. (1999) Robustness of Simple Monetary Policy Rules under Model Uncertainty. In: de Taylor, J.B., Ed., Monetary Policy Rules, University Press of Chicago, Chicago, 263-299. https://doi.org/10.2139/ssrn.148695

[3] Dewald, W.G. and Johnson, H.G. (1963) An Objective Analysis of the Objectives of American Monetary Policy 1952-1961. In: Carsen, Banking and Monetary Studies, Irvine Publishing Company, Homewood, 171-186.

[4] Rudebusch, G.D. (1995) Federal Reserve Interest Rate Targeting, Rational Expectations and the Tern Structure. Journal of Monetary Economics, 35, 245-274.

[5] Rudebusch, G.D. and Svensson, L.E. (1999) Policy Rules for Inflation Targeting. In: Taylor, J.B., Ed., Monetary Policy Rules, University of Chicago Press, Chicago, 203-246.

[6] Sachs, G. (1996) The International Economic Analyst. Vol. 11, Issue 6.

[7] Sack, B. and Wieland, V. (2000) Interest-Rate Smoothing and Optimal Monetary Policy: A Review of Recent Empirical Evidence. Journal of Economics and Business, 
52, 205-228.

[8] Orphanides, A. (1998) Monetary Policy Evaluation with Noisy Information. Journal of Monetary Economics, 50, 605-635.

[9] Kozicki, S. (1999) How Useful Are Taylor Rules for Monetary Policy. Federal Reserve Bank of Kansas City, Economic Review, Second Quarter, 5-33.

[10] Clarida, R., Gali, J. and Gertler, M. (1998) Monetary Policy Rules in Practice: Some International Evidence. European Economic Review, 42, 1033-1067.

[11] Clarida, R., Gali, J. and Gertler, M. (2000) Monetary Policy Rules and Macroeconomic Stability: Evidence and Some Theory. Quarterly Journal of Economics, 115, 147-180. https://doi.org/10.1162/003355300554692

[12] Svensson, L. (1999) Inflation Targeting as Monetary Policy Rule. Journal of Monetary Economics, 43, 607-654.

[13] Svensson, L. (2000) Open-Economy Inflation Targeting. Journal of International Economics, 50, 155-183.

[14] Svensson, L. (2002) What Is Wrong with Taylor Rules? Using Judgment in Monetary Policy though Targeting Rules. Journal of Economic Literature, 41, 426-477.

[15] Woodford, M. (2004) Inflation Targeting and Optimal Monetary Policy. Federal Reserve Bank of St Louis Review, 86, 15-41.

[16] Christiano, L., Hut, C.L., Mottor and Rostagno, M. (2010) Monetary and Stock Market Booms. European Central Bank, Working Papers Series 955/October 16402. https://www.ecb.europa.eu/pub/pdf/scpwps/ecbwp955.pdf

[17] Issing, O. (2011) Lessons for Monetary Policy: What Should the Consensus Be? IMF Working Paper. https://www.imf.org/external/pubs/ft/wp/2011/wp1197.pdf

[18] Curdia, V. and Woodford, M. (2010) Credit Spreads and Monetary Policy. Journal of Money, Credit and Banking, 42, 3-35. https://doi.org/10.1111/j.1538-4616.2010.00328.x

[19] Tinbergen, J. (1952) On the Theory of Economic Policy. North Holland, Amsterdam.

[20] Ball, L. (1999) Policy Rules for Open Economies. In: Taylor, J.B., Ed., Monetary Policy Rules, University Press of Chicago, Chicago, 127-154.

[21] Ball, L. (2000) Policy Rules and External Stocks. NBER Working Paper n W7910.

[22] Mundell, R. (1963) Capital Mobility and Stabilization Policy under Fixed and Fixed and Flexible Exchange Rates. Canadian Journal of Economics and Political Science, 29, 475-485. https://doi.org/10.2307/139336

[23] Pavasuthipaisit, R. (2010) Should Inflation-Targeting Central Banks Respond to Exchange Rate Movements? Journal of International Money and Finance, 29, 460-485.

[24] Filosa, R. (2001) Monetary Policy Rules in Some Mature Emerging Economies. Bank for International Settlements Papers, 8, 39-68.

[25] Corbo, V. (2002) Monetary Policy in Latin America in the 1990s. In: Loayza, N. and Schmidt-Hebbel, Eds., Monetary Policy: Rules and Transmission Mechanisms, Central Bank of Chile, Santiago.

[26] Mohanty, M.S. and Klau, M. (2004) Monetary Policy Rules in Emerging Market Economies: Issues and Evidence. Bank of International Settlements. BIS Working Papers No. 149. http://papers.ssrn.com/sol3/papers.cfm?abstract_id=901388

[27] Avouyi-Dovi (2013) Estimation d'une fonction de réaction pour la Banque Centrale des Etats de l'Afrique de l'Ouest, Notes d'information et statistiques de la BCEAO, 
mars 2013.

[28] Kamgna, et al. (2009) Fonction de réaction de la Banque Centrale et crédibilité de la politique monétaire: Cas de la BEAC. http://mpra.ub.uni-muenchen.de/16557/

[29] Orphanides, A. (1997) Monetary Policy Rules Based on Real-Time Data. The American Economic Review, 964-999.

[30] Johansen, S. (1991) Estimation and Hypothesis Testing of Cointegration Vectors in Gaussian Vector Autoregressive Models. Econometrica, 59, 1551-1580.

https://doi.org/10.2307/2938278 


\section{Appendix}

Appendix 1. Calculation of the real equilibrium exchange rate.

\begin{tabular}{|c|c|c|c|c|c|c|}
\hline & Tc & Export price & Import price & tcer & $\begin{array}{c}\text { hptcer (Filtre } \\
\text { de Hodrick } \\
\text { Prescott) }\end{array}$ & tcer_equilibrium \\
\hline 1980 & $211,279,555$ & 0.60783473 & 0.98741966 & $130,059,241$ & $212,347,745$ & $300,247,672$ \\
\hline 1981 & $271,731,453$ & 0.53778557 & 0.79363738 & $184,131,013$ & $211,830,243$ & \\
\hline 1982 & $328,606,253$ & 0.59453631 & 0.74951355 & $260,660,197$ & $210,489,855$ & \\
\hline 1983 & $381,066,036$ & 0.51123699 & 0.7093301 & $274,646,533$ & $207,226,705$ & \\
\hline 1984 & $436,956,666$ & 0.45735715 & 0.68355335 & $292,362,338$ & $201,442,618$ & \\
\hline 1985 & $449,262,963$ & 0.47011384 & 0.7893647 & $267,562,936$ & $19,321,362$ & \\
\hline 1986 & $346,305,904$ & 0.38550173 & 0.76126396 & $175,368,247$ & $183,524,931$ & \\
\hline 1987 & $300,536,562$ & 0.41273229 & 0.9543681 & $129,972,012$ & $174,105,266$ & \\
\hline 1988 & $297,848,219$ & 0.38175126 & 0.92097856 & $123,459,913$ & $166,601,774$ & \\
\hline 1989 & $319,008,299$ & 0.38007879 & 0.95889861 & $126,445,368$ & $162,220,269$ & \\
\hline 1990 & $272,264,788$ & 0.42860285 & 0.9231691 & $126,405,297$ & $161,735,149$ & \\
\hline 1991 & $282,106,909$ & 0.41754402 & 0.85288676 & $138,109,836$ & $16,556,306$ & \\
\hline 1992 & $264,691,801$ & 0.40253251 & 1.01751671 & $10,471,283$ & $173,767,352$ & \\
\hline 1993 & $28,316,258$ & 0.32558162 & 0.74719374 & $123,385,041$ & $186,136,843$ & \\
\hline 1994 & $555,204,696$ & 0.33395682 & 0.67537787 & $274,534,308$ & $201,769,803$ & \\
\hline 1995 & $499,148,426$ & 0.35312314 & 0.76935939 & $229,100,806$ & $219,136,987$ & \\
\hline 1996 & $51,155,243$ & 0.3982991 & 0.79979372 & $254,754,276$ & $237,436,793$ & \\
\hline 1997 & $583,669,372$ & 0.34986227 & 0.7099454 & $287,633,237$ & $255,967,258$ & \\
\hline 1998 & $589,951,775$ & 0.27635016 & 0.60983005 & $267,342,132$ & $274,199,594$ & \\
\hline 1999 & $615,699,132$ & 0.32633638 & 0.67624205 & $297,119,985$ & $291,921,673$ & \\
\hline 2000 & $711,976,274$ & 0.41704237 & 0.75307141 & $394,284,351$ & $308,852,791$ & \\
\hline 2001 & $733,038,507$ & 0.36658663 & 0.76322764 & $352,086,462$ & $324,764,229$ & \\
\hline 2002 & $696,988,204$ & 0.39086102 & 0.92168936 & $295,571,951$ & $340,281,582$ & \\
\hline 2003 & $581,200,314$ & 0.4791564 & 0.96050803 & $289,935,995$ & $356,303,668$ & \\
\hline 2004 & $528,284,809$ & 0.63194736 & 1.06228809 & $314,272,742$ & $37,328,221$ & \\
\hline 2005 & $527,468,143$ & 0.81643144 & 1.0878634 & $395,859,974$ & $391,005,251$ & \\
\hline 2006 & $52,289,011$ & 0.93841382 & 1.17201874 & $418,668,483$ & $408,670,742$ & \\
\hline 2007 & $479,266,783$ & 0.94833892 & 0.99900138 & $454,961,675$ & $425,525,181$ & \\
\hline 2008 & $447,805,256$ & 1.21891779 & 1.13667344 & $480,206,338$ & $440,915,042$ & \\
\hline 2009 & $472,186,291$ & 0.85212586 & 1.00635059 & $399,823,036$ & $454,481,166$ & \\
\hline 2010 & $495,277,022$ & 1 & 1 & $495,277,022$ & $466,257,305$ & \\
\hline 2011 & $471,866,114$ & 1.21598462 & 1.12404193 & $510,463,111$ & $47,573,063$ & \\
\hline 2012 & $510,527,136$ & 1.16727285 & 1.09853619 & $542,471,402$ & $482,678,512$ & \\
\hline 2013 & $494,040,037$ & 1.17527206 & 1.14428902 & $507,416,782$ & $487,225,642$ & \\
\hline 2014 & $494,414,953$ & 1.09733534 & 1.14701508 & $473,000,754$ & $490,094,643$ & \\
\hline \multirow[t]{2}{*}{2015} & $591,449,508$ & 0.67751583 & 0.96129511 & $416,850,558$ & $492,210,049$ & \\
\hline & & & & & $300,247,672$ & \\
\hline
\end{tabular}


Submit or recommend next manuscript to SCIRP and we will provide best service for you:

Accepting pre-submission inquiries through Email, Facebook, LinkedIn, Twitter, etc. A wide selection of journals (inclusive of 9 subjects, more than 200 journals)

Providing 24-hour high-quality service

User-friendly online submission system

Fair and swift peer-review system

Efficient typesetting and proofreading procedure

Display of the result of downloads and visits, as well as the number of cited articles Maximum dissemination of your research work

Submit your manuscript at: http://papersubmission.scirp.org/

Or contact me@scirp.org 